JOURNAL OF

French and Francophone Philosophy
REVUE DE LA

philosophie française et de langue française

\title{
The Concept in Life and the Life of the Concept: Canguilhem's Final Reckoning with Bergson
}

\section{Alex Feldman}

Journal of French and Francophone Philosophy - Revue de la philosophie française et de langue française, Vol XXIV, No 2 (2016) 154-175.

\author{
Vol XXIV, No 2 (2016) \\ ISSN 1936-6280 (print) \\ ISSN 2155-1162 (online) \\ DOI 10.5195/jffp.2016.775 \\ www.jffp.org
}

\section{(c) EY-NC-No}

This work is licensed under a Creative Commons Attribution-Noncommercial-No Derivative Works 3.0 United States License.

\section{ULIS D-Sunk}

This journal is operated by the University Library System of the University of Pittsburgh as part of its D-Scribe Digital Publishing Program, and is co-sponsored by the University of Pittsburgh Press 


\title{
The Concept in Life and the Life of the Concept
}

\author{
Canguilhem's Final Reckoning with Bergson
}

\author{
Alex Feldman \\ Pennsylvania State University
}

To read Georges Canguilhem and Henri Bergson together in North America, it is necessary first to dispense with a certain folklore about the history of twentieth-century French philosophy. Foucault famously divided that history between "a philosophy of experience, meaning, and the subject" and a "philosophy of knowledge, rationality, and the concept," with Bergson ranged in the first camp and Canguilhem in the second. ${ }^{1}$ Unsuspecting readers have often failed to realize that this proclamation was in fact a complex rhetorical gesture: a quotation of statements made by Canguilhem a decade earlier in response to Sartre. ${ }^{2}$ What is true is that the Anglophone reception of Bergson and Canguilhem has been quite different. Bergson had fallen into nearly total oblivion by the beginning of the 1960 s, only to enjoy a minor revival in continental philosophy due in large measure to Deleuze. ${ }^{3}$ For his part, Canguilhem has remained a more peripheral figure. ${ }^{4}$ The success of Dominique Lecourt's influential if outdated Marxism and Epistemology: Bachelard, Canguilhem, Foucault explains in part why Canguilhem, when read at all, is often assimilated to the current in the philosophy of science called "historical epistemology." 5 The rediscovery, however, of a number of juvenilia and occasional writings and the publication of Canguilhem's CEuvres complètes has produced a shift in the Francophone interpretation towards Canguilhem's broader philosophy of values and philosophy of life. ${ }^{6}$ As it turns out, Canguilhem was a careful and frequent reader of Bergson. Rethinking Canguilhem's philosophical project today requires us to return to his complicated relationship with Bergson. ${ }^{7}$

If, to speak like Bergson, Canguilhem possesses a basic philosophical intuition, it is that philosophy must necessarily seek out what is strange or foreign to it, but not in order to reduce it to the identity of the philosophical concept: "Philosophy is a reflection for which all foreign material is good, 
and we would gladly say for which all good material must be foreign." 8 Canguilhem refused the closure of the history of philosophy upon itself and, much like Bergson, wanted to reinvigorate philosophy through contact with the history of scientific and technical practices. ${ }^{9}$ Yet Canguilhem did not abandon philosophy for a scientistic positivism. Indeed, in "Le concept et la vie" ("The Concept and Life"), he interweaves the history of biology with a drawn-out battle between Aristotle and Bergson on the questions of the being of life and the possibility of biological knowledge. ${ }^{10}$ This 1966 essay represents a kind of final reckoning with Bergson, whom Canguilhem had first begun to read appreciatively in the late 1930s.11 But the particular problem that preoccupies him in 1966 is the relation between human knowledge of life and the "logic of life" itself as formation of forms, between vital order and the thought of that order.

In the first section, I will cover the basic argument of "Le concept et la vie," emphasizing Canguilhem's criticisms of Bergson. The second section will address these criticisms from Bergson's perspective, but also restore the original way in which he thinks the problem of vital order. Many of Canguilhem's criticisms, I will argue, fall short because they fail to take into account Bergson's rethinking of ontology, but I will return, in the final section, to several deep points of similarity even after the 1966 essay.

"Le concept et la vie" appears at first glance to address a modification of the Kantian theme: how knowledge of life is possible? The answer would then be a strong realism: the general concepts according to which biology thinks living beings are already in life itself, rather than being projections of the mind's own organizing tendencies. ${ }^{12}$ What is surprising about the text, especially given Canguilhem's earlier works, is that the question seems to have been answered by developments in the sciences themselves and not by philosophy. The displacement of mechanical concepts in biology by information concepts and the discovery of the structure of DNA suggests a return to Aristotelianism: "To say that biological heredity is a communication of information is, in a certain sense, to return to Aristotelianism, if it means admitting that there is a logos in the living being that is inscribed, conserved, and transmitted. [...] To define life as a sense inscribed in matter is to admit the existence of an objective a priori, a properly material and no longer merely formal a priori."13

Yet, against any claim that scientific results of themselves are sufficient to determine answers to philosophical questions, Canguilhem proceeds by way of a lengthy history of philosophical treatments of the problem of concept and life that is not limited to how knowledge is possible, but also extends to what knowledge is. As he famously concludes the essay, "Contemporary biology, read in a certain way, is in some sense a philosophy 
of life." Does this "read in a certain way" entail a specifically philosophical eye? Just before this sentence, Canguilhem has asked: "What then is knowledge [connaissance]? [...] If life is sense and concept, how should we conceive knowing?"14 Knowing, in other words, is not taken to be a sui generis form of activity, but rather as a special way of living. Consequently, if the essay has bearing on epistemological concerns, it hardly approaches them from the vantage of a search for absolute foundations in the face of Cartesian skepticism. The opening lines of the essay clarify, indeed, that the possibility of biological knowledge is only one of the questions to be addressed. Life (la vie) in French can suggest either "the universal organization of matter" or the "lived experience" of a particular organism, what Canguilhem calls the difference between vivant and vécu. He claims that the former takes philosophical property over the latter. ${ }^{15}$ By starting with the vivant, in the sense not of the singular living being but of what is "living in the living," Canguilhem goes back behind the traditional epistemological division between subject and object to the point from which both arise, presumably to something like the natura naturans of life as production both of forms and of the modes of knowing these forms. ${ }^{16} \mathrm{He}$ is interested in both the "nature and value" of the concept and the "nature and sense [sens] of life."17 In other words, Canguilhem's is pursuing a critical investigation into the normativity not merely of certain concepts, but of biological knowledge itself - the question of the value of knowing, the value of the truth.

Starting with the vivant puts out of play all intellectualist theories of knowledge that presuppose a timeless ontology of archetypal ideas or an equally timeless table of categories certified by a transcendental subject. But without these traditional options, it becomes difficult to account for the order that life exhibits, its amenability to being grasped under concepts. The problem of order in biological nature thus unfolds along two axes in Canguilhem's own thought: first, the distinctiveness of that order from the physical order of matter and, second, the "source" of the order of life. One way to address the second problem would be to find the source of this order in life itself (Aristotle's solution). In this case, the concept is both substance and definition, ousia and logos; to go one step further, Aristotle treats order in the terms of a logic of classification. As unity in difference, the concept then finds its reality in the genera and species of the natural world. ${ }^{18} \mathrm{~A}$ philosophy of the immanence of order to life itself, taken to its natural conclusion, must treat that which grasps this order (the mind) as immanent to life as well. Such a naturalistic and classifying approach must then take the intellect itself as simply one more natural character indicative of a specific difference, much as the claw or a beak might be the defining difference between other animal species within a common genus. Yet the openness of human intelligence to an infinite horizon of knowledge attests a profound disanalogy between the mind and, for example, the claw: reason is a capacity to know (potentially) all the forms that make up the natural 
order. ${ }^{19}$ In this sense, and unlike other organs, the scope of what the intellect can seize or grapple with is unbounded.

As for the first problem (the relationship between vital and material order), Aristotle rejects any "mathematical model of the living being." His biological concepts are only the realization of a "non-deliberative natural logos," the realization of nature's "art" and not that of a calculating "artisan" or craftsman. ${ }^{20}$ It is within this framework that Canguilhem introduces his first set of objections to Bergson. First, in condemning all of Greek metaphysics for ignoring the reality of duration in Chapter IV of Creative Evolution, ${ }^{21}$ Bergson neglected the difference between Plato and Aristotle on mathematics and thus conflates mathematics with logical classification; second, Bergson retains an antiquated idea of mathematics as the measuring geometry of the homo faber, despite a profound transformation of geometry by Gaspard Monge and Jean-Victor Poncelet away from the model of space that is the object of Bergson's unending critique and toward a focus on qualities and alterations. Finally, Bergson is ignorant of genetics. In sum, one finds here the "philosophical theme" of the "incompatibility of knowledge and life," as it is "often played with what we could call a Bergsonian accompaniment." The ambition of Bergson's philosophy is reduced to the tired early twentieth-century cliché that life escapes all knowledge and the knowledge is inimical to life. Bergson is taken to have argued that life is fundamentally becoming (devenir) and that all repetition of forms, e.g., the morphological similarities of members of a species, is merely a "generalization" of infinitesimal and constantly changing individual variations. ${ }^{22}$ We might say that Bergson has merely inverted Platonism but has not overcome it: being (repetition) is inverted into the inessential and becoming (difference) into the essential.23 Genetics, Canguilhem holds, refutes this treatment of stability and repetition as merely phenomenal by demonstrating the existence of a material basis of transformation in the genetic code passed along between generations of a species. ${ }^{24}$

This first swipe at Bergson is, however, directed less at the philosopher himself than at what might be called a certain version of "Bergsonism." 25 For our purposes, the most significant claim will turn out to be the proximity of Bergson to Aristotle's sense of the non-mathematical production of vital forms - a question of art. In the remainder of the first section of the essay, Canguilhem gives a broad critical account of nominalism and the problem of resemblance, ending with a discussing of Kant and Hegel. ${ }^{26}$ Rather than explore the richness of what amounts to a general history of the philosophy of life, however, I will focus for the remainder exclusively on the criticisms of Bergson.

My worry is that by starting from a certain Bergsonism rather than from Bergson, Canguilhem risks distorting the latter precisely on the point that is so often held to be his stumbling block: the question of repetition. The caricature of Bergson in the first section of the essay, as well as the 
juxtaposition of those pages with the subsequent discussion of individuality and nominalism, risk making Bergson himself into a nominalist, in spite of his explicit rejection of the basic postulate of nominalism: the existential primacy of individuals. ${ }^{27}$ To Canguilhem's credit, he is hardly content to reduce Bergson to an image based on little more than a hasty reading of Creative Evolution. For this reason, he returns to the problem of repetition and generality in the second section of his article, where he engages much more carefully with the arguments of Bergson's other philosophical works. ${ }^{28}$ The argument moves in three stages: from a general claim about the creative duration of life in Creative Evolution, to a reading of the discussion of the general idea in Chapter III of Matter and Memory, and thence to a supposed shift in Bergson on the general idea that occurs in the second introduction to The Creative Mind. ${ }^{29}$

1. Canguilhem quotes: "Real duration is that in which each form flows out of previous forms, while adding to them something new, and is explained by them as much as it explains them." 30 From this statementwhich occurs near the end of the book in the context of a critique of postKantian philosophical systems-Canguilhem concludes that the novelty introduced by duration is not deducible from any concept or prior model and hence can "only be grasped by an intuition." 31 In other words, the living form is not the realization of an idea, of a possibility. But from this claim it in no way follows that the production of a vital form is unintelligible, a pure event. Canguilhem does not appear to recognize here that he has given only half the story, for, after the fact, the "simple movement" of duration is decomposable into a limitless number of ideas from which, retroactively, an explanatory chain of events can be constituted.32 It is strange that Canguilhem has chosen to draw a definition of duration in Bergson from this particular passage.

2. Canguilhem believes that Bergson runs into difficulty in accounting for the origin of concepts. First, in the famous discussion of general ideas from Matter and Memory, ${ }^{33}$ Bergson roots consciousness in the utilitarian actions of the embodied living being, where the complexity of physiological and anatomical structure means that a certain "zone of indetermination" opens up in the organism's comportment-a kind of vital and practical freedom. From this indetermination, need (besoin) operates a process of selection of useful resemblances that brings about a regularity of external stimulus on the organism and response by the organism. In other words, the general idea is thought on the model of the acquisition ("contraction") of a habit. Hence the famous passage that Canguilhem cites: "But need goes straight to the resemblance or quality; it cares little for individual differences... It is the grass in general which attracts the herbivore." 34 Canguilhem reads this contraction of a habit as the "imprinting" on the body of a certain stability of habits and attitudes, that is, a "lived and felt resemblance, or, if you prefer, a resemblance automatically played out." 35 
According to Canguilhem, Bergson makes appeal ("en quelque sorte") to the model of "reflex functions in the nervous system" to understand this habitforming process. From this prefiguration of the general idea that is given mechanically, reflection leads to the idea of the general idea in general - the genus (genre). ${ }^{36}$

3. The Creative Mind, finally, leads in a new direction: Bergson moves "from the idea of resemblance as identity of organic reaction to the idea of resemblance as identity of the nature of things." 37 The shift is from a physiological to a more broadly biological perspective. Generalization is a function proper to all living beings at all levels. ${ }^{38}$ I have restored the full passage from which Canguilhem cites:

[I]t still remains for us to find out how natural general ideas, which serve as a model to others, are possible, and why experience presents us with resemblances which we have only to translate into generalities. Among these resemblances there are some, naturally, which go to the fundamental root of things. [...] It might be useful, therefore, at this point to digress upon what one might call objective generalities, inherent in reality itself. ${ }^{39}$

Of the three types of general ideas discussed by Bergson - vital, geometric, and those produced by society and fabrication - the first two can be said to be founded upon "objective generalities," but not in the same way. The resemblances detected in unorganized matter are, at the limit, mathematical and measurable identities, whereas what Bergson calls vital resemblances truly are resemblances and not merely "partial identities." 40

Bergson does not, unfortunately, explicitly spell out the relationship between the "objective resemblances" of biology and biological ideas. Canguilhem notes that Bergson tends to use the language of the "as if" (comme si): in the structuration of living beings, the resemblance of properties, and the hierarchical arrangement of living beings according to the scale of transmission, life acts or works as if it were following a concept. ${ }^{41}$ But whereas the Kantian "as if" points to the limits of reason and signifies intellectual prudence, Bergson's "as if" comes with no such modesty. Thus Bergson ends up with "a sort of connivance [connivence] between life and the knowledge of life" rather than with Aristotelian identity or Kantian agnosticism, an inexplicable collusion that looks suspiciously like preestablished harmony. ${ }^{42}$ Vital repetition would then be inexplicable except for the grace God, or rather except for what Jankélévitch called the secret proposition of Bergson's philosophy: the finitude of the élan vital. ${ }^{33}$ Life imitates the concept only because it cannot overcome every obstacle it faces. The source of repetition would then be the exhaustion of life's creativity and the ensuing stupor. But we should be careful in reading this "secret proposition": Bergson's claim is not that life would have remained simple and undifferentiated were it not for the intrusion of matter-such a 
metaphysics is, carried to the extreme, Manicheanism. Life as will and durée is first of all self-differentiation: it is more like an artillery shell (obus) that bursts apart into fragments in its very movement than a cannonball (boulet) that remains unitary across its arc. ${ }^{44}$

In sum, Bergson depreciates speciation and repetition of form. Now, if we know today that the process of transmission occurs by way of a material component, Bergson does not stand refuted simply on a scientific basis alone. Canguilhem accuses Bergson of failing to make sense of the centrality to life of the struggle to maintain a species form. ${ }^{45}$ If life is creation and the upsurge of novelty for Bergson, Canguilhem's conception is more focused on resistance to death and sickness. They differ not only in the science they use, but also in how each of them "reads" it philosophically. 46 In Canguilhem's case, however, what philosophy reads is already a reading: of the genetic code of life.

Canguilhem holds that the discovery of the structure of DNA returns us to a kind of Aristotelianism. Knowledge of life is now a matter of deciphering or reading the material "message" or "logos" inscribed in life itself; life is essentially text. ${ }^{47}$ As Michel Morange has observed, this interpretation of genetics as a text is outdated today and misunderstands the science even of the 1960s; the structure of proteins-let alone "innate patterns of behavior" - cannot be directly deduced from the genetic code, but presupposes an historical relationship with the milieu. ${ }^{48}$ Philosophically, Canguilhem faces three major difficulties. First, he seems to slip from the metaphor of "reading" the genetic code to one of "finding" explanatory "keys": he risks sliding into a precritical theory of knowledge that ignores how much this reading is instructed and prepared by the development of mathematics, instruments, and techniques. Second, a massive slippage has happened in the notion of the concept itself, which is hardly the general classificatory idea discussed earlier in the essay. Can the forms of modern biology be said to have anything more than a mere etymological resemblance to the forms of Aristotle's biology? More precisely, the genesis and development of living beings does not proceed strictly according to a concept in the older sense (a unitary form where the end is contained in the beginning), but rather the unity and solidity of a species form is itself only a momentary stabilization. Canguilhem himself cites Louis Roule's expression that all forms are simply "normalized monsters" in a history of mutations. 49 Finally, an equally important slippage happens in the concept of reading itself: can there be anything but a play on words that connects the reading of DNA in the formation of proteins, the reading of the genetic code by biology, and the reading of biology by philosophy?

Canguilhem's surprising move in the final pages of the article is to draw a heavy analogy between "inborn errors of metabolism" and epistemic errors. ${ }^{50}$ He founds the human recherche de la vérité on error, understood as the errancy and displacement of the human organism, rather than a 
teleological relation to the essence of things. In other words, the logos or sense in life is nothing stable (its form is not produced by a divine artisan), but is rather the outcome of a contingent process of evolution, a momentary "normalization" (Roule) of mutations. "La vie aurait donc abouti par erreur à ce vivant capable d'erreur" ("life would then have ended up by error [i.e., through mutation and through errors of genetic transmission] at this living being capable of error"). ${ }^{51}$ In turn, the human being is always errant (wandering), i.e., without fixed domicile or habit, and it is precisely this errancy that makes knowledge, as another vital function, open to an everincreasing variety of information and to the experience of error that breaks with immediate satisfaction in the thing known. The openness of the concept as form to a limitless content is thus the result of a certain history of rectified errors, a history of the errancy or restlessness of the concept itself. For these reasons, as we will see, Canguilhem's vital concept hardly imprisons life in a fixed form.

\section{II}

We have already expressed a worry that Canguilhem's target is not really Bergson, but rather a certain Bergsonism. On three points, his reading is suspect: his understanding of duration, his interpretation of habit as reflex, and, above all, his reading of The Creative Mind. Nevertheless, in other areas, Canguilhem is closer to Bergson than he sometimes suspects. Before addressing, then, these three points, we will have to reconstitute the problem of vital order as it arises on Bergson's own terms.

Recall first of all that the stated ambition of Creative Evolution is twofold, even if the conventional wisdom focuses only on the first aspect, the philosophy of life. In fact, Bergson believes that taking evolution in its creativity seriously means radically rethinking the theory of knowledge as well. 52 The intelligence is also in life and thus in natural history, which means the power of understanding must have a history or genesis as well; an evolutionary philosophy worthy of its name cannot cheat here by smuggling back in teleological or preformationist principles. But this is precisely what even philosophers (Fichte, Spencer) who pretend to take the problem of the genesis of the intelligence seriously end up doing. ${ }^{53}$ Bergson approaches the problem of genesis along two axes. The first, given in the treatment of the "diverging lines of evolution" in Chapter II, challenges the traditional reading of intelligence as a perfected or sublated instinct. Instinct and intelligence share a common origin, granting, as always in Bergson, that this original impulsion or élan vital is an "unstable balance [équilibre] of tendencies" that proceeds by division. ${ }^{54}$ What results is a movement of differentiation where the differences in question (the development of intelligence and of instinct) are in kind and not in degree.55 Instinct and intelligence cannot be said to be contained in the original tendency (tendance) 
as two preformed possibilities, but are instead "reciprocally implied" in one another like two psychological states in an indistinct multiplicity. ${ }^{56}$ They represent two "radically different kinds of knowledge." 57 Both instinct and intelligence are pragmatic and utilitarian faculties of adaptation to nature, but the first adapts to organized nature, whereas the second adapts to unorganized nature (matter).

The second, and more radical move, comes in Chapter III, where Bergson passes from the theory-of-knowledge perspective to the mutual implication of epistemology and metaphysics, of mind and nature. Bergson's task now is to show the reciprocal genesis of matter and the intelligence from out of the original élan by shifting to a quasi-cosmological perspective. ${ }^{58}$ In other words, neither term is taken as the origin of the other: Bergson eschews both a materialist account of the genesis of the mind from matter and an idealist account of the genesis of matter from mind. Instead, the two are co-constitutive, or rather they represent two distinct tendencies of the original élan. Without going into the details of this move, I would like to emphasize the relationship between the problem of the reciprocal genesis of matter and the intelligence in Creative Evolution and the twin critique of realism and idealism in Matter and Memory. ${ }^{59}$ In this Preface added to latter in 1910, Bergson praises Berkeley, who refused the early modern rejection of the reality of secondary qualities, as found, for example, in Descartes, for whom the fundamental reality of material things is their geometrical extension. Yet Berkeley's idealism goes so far in the other direction that it makes the mathematical order that exists in the universe unintelligible without the intervention of God: he saves the secondary qualities of matter precisely by making matter an idea. That is, from the extreme of Descartes, for whom the essence of things is the geometrical relationship between them, Berkeley goes toward the other extreme by placing matter in the mind. From the perspective of Bergson's theory of the primacy of images (the image as existing "in itself" and "in between" or mi-chemin between divisible and material repeatability and the ideal unity), however, it could be possible to avoid the Kantian solution to the crisis provoked by Berkeley and Hume, as well as Kant's sacrifice of metaphysics to physics. Kant guarantees the rationality of mathematical physics by critically limiting the validity of the senses and the ambitions of the understanding. Now, argues Bergson, starting with images allows philosophy to make the mathematical order of the universe intelligible without this process of intellectual self-limitation necessitated by the Kantian critique. 60

If epistemology and ontology as diverging philosophical projects have grown out of the Kantian rupture, that is, out of a choice between idealism and realism concerning the origin of order in the universe, Bergson instead poses the problem of order in itself, prior to the divergence of these two tendencies. ${ }^{61}$ Now, this problem of order is to a certain extent a nonproblem, as Bergson famously argues across his later work; to ask "why is 
there order and not rather disorder" is to import a certain pragmatic experience, our powerlessness in the face of an order that is superior to our capabilities, into the realm of speculation. ${ }^{62}$ The problem of knowledge, at least in its radical Cartesian variety of the threat of absolute unintelligibility, is a false problem, as Bergson argues a number of times: it rests on the idea of the possibility of radical or absolute disorder and incoherence in the world. Such a disorder is, however, inconceivable to us except by way of a false generalization of our general ideas, and every actual representation of a disorder is merely that of another order that we have not mastered. ${ }^{63}$ In sum, the problem of disorder is based upon the "intellectualist illusion" that the whole of reality can be represented in a concept and thence negated. ${ }^{64}$

Consequently, the mutual implication of the theory of knowledge and the philosophy of life proposed by Bergson in the Introduction to Creative Evolution should be seen as merely a provisional step toward a superior philosophical position that surpasses the configuration of problems bequeathed by the post-Cartesian tradition, dependent as they are upon the artificial separation of subject and object. By this I do not mean that epistemology utterly evaporates, but that its problems are placed in appropriate perspective and even change shape. One such new problem is to account for the simultaneous openness and restriction of knowing, what in traditional rationalism is seen as the limitlessness of the power of the understanding to bring reality under its concept, confronted with the very real limits of actual knowledge (or, in the Kantian sense, the recognition of the limits of the understanding). In fact, if the subject of knowledge and object of knowledge share a common root in Bergson, the problem might seem instead to be how the mind does not already reach the essence of all things, but of course the mind is not this limitless and transcendental power in Bergson. Intellectual knowledge is practical adaptation to working with matter, but the adaptation requires effort, which means that it does not follow automatically or mechanically from matter but requires the "solution of problems," the creation of new habits. 65 The growth of knowledge then is the problem of breaking through the barriers created by old intellectual habits in order to open the mind to conceptual creation: it will be the problem of intuition.

On the other hand, the special problem of knowledge of life remains. Intelligence, as fabrication, entails the giving of a form to a matter. But insofar as the aim of fabrication is the form, at the limit any matter will suffice. At the most extreme, this "indifference" of the matter to the form gives us a homogeneous space that can be decomposed or cut up however we wish; the intelligence thus projects such a partes extra partes space as the "schema" of all of our possible actions upon matter. 66 The limitlessness of the operations of the intelligence runs up, however, against its natural inability to comprehend the indistinct multiplicity that is life. ${ }^{67}$ From this sort of remark uncharitable readers have sometimes assumed that life is 
impenetrable to concepts, general ideas, symbols, language, or anything else that depends upon the repeatability of a form. At the limit, life is pure singularity to be felt in intuition, and the letter is taken to be abnegation of the possibility of knowing (whereas we have seen in fact that Bergson's project rejects the Kantian critique's limitation of reason for the sake of metaphysics). ${ }^{68}$ Any repetition of vital forms would only be a kind of betrayal of the élan vital's undifferentiated creative movement, and all conceptual knowledge of life would attain only life's illusory underside.

Canguilhem's criticisms of Bergson can now be situated more precisely: Canguilhem rejects the epistemologically defeatist reading of Creative Evolution, but he accepts its basic terms. He is therefore led to neglect the crucial way in which the 1907 book sets up a difference in kind between two types of order, geometrical and vital. Vital order is not simply a poor imitation of identity.

We can now address the three missteps in Canguilhem's argumentation:

1. Duration (durée). Bergson's idea of duration treats the succession or progression of time positively, as neither a lack of present co-existence nor a "privation of eternity," but rather as an upsurge of novelty and unforeseeability (imprévisibilitê). ${ }^{69}$ Duration names the time of existence and of change, not as a succession of states, but as the unpredictable upsurge of novelty in a continuous temporal movement or evolution, a kind of nonteleological ripening or maturing. ${ }^{70}$ Recall that Canguilhem equates this centerpiece of Bergson's thought with pure and unconditioned creativity. ${ }^{71}$ To be sure, Bergson does sharply criticize the notion of possibility, according to which the real would pre-exist its coming to presence in an idea or concept. Yet it is not true that creative evolution is thereby rendered utterly inaccessible to concepts. Put differently, while the end (the future) is not contained in the beginning (the present), the future does not advent without a profound relationship to the past. We could say that this is the problem of memory and of virtuality (evolution is an "organic memory"): duration signifies not a radical break with the past, but rather that the ground or cause of the future event lies in the totality of the past of a living body and not in the immediate past. ${ }^{72}$ Duration is neither one nor multiple: it is differentiated according to mutually implicated tendencies, that is, its parts are constituted by their interrelations. Life is

An immensity of virtuality [virtualité], a mutual encroachment of thousands and thousands of tendencies which nevertheless will only be 'thousands and thousands' once each has been exteriorized with respect to the others, that is, once spatialized [ne seront pourtant 'mille et mille' qu'une fois extériorisées les uns par rapport aux autres]. Contact with matter is what decides [décide de] this dissociation. Matter divides actually what was but virtually 
multiple; and, in this sense, individuation is in part the work of matter, in part the effect of what life bears in itself [ce que la vie porte en elle $] .73$

Elsewhere Bergson calls duration an "indistinct" or "intensive" multiplicity. ${ }^{74}$

As Pete Gunter has noted, in the Bergsonian account of creative evolution, certain general tendencies and characteristics can be observed from a more global perspective on life: "Expressions of creativity, whether in biological evolution or elsewhere, for him always exhibit the same five characteristics: 1) divergence; 2) increased spatiality $[. .$.$] ; 3) elaboration of$ spatial form; 4) repetition in time [..]; and 5) unique temporalities (biological times)."75 In other words, life exhibits certain unities-indifference, certain repeated characters, that can be brought under concepts, but only once the congealed concepts inherited from mechanism and finalism, such as organization, vital effort, materiality, order, are radically re-worked, and biological cause, correlation of traits, adaptation, and vital principle.76 Grasping the specificity of vital repetition or resemblance requires a particular effort to go beyond inherited habits of thought.

2. Canguilhem thus misses the intrication of the past, the involvement of memory, in the advent of the new, but this oversight leads him to misread as well the account of the general idea in Chapter III of Matter and Memory. To explain the origin of general idea from perception, Bergson affirms the notion of resemblance but rejects both conceptualism and nominalism, which rest on the common postulate that initially we encounter only individuals; instead, we start with the perception of useful resemblances, and the general idea has its origin in habit, in the similarity of reaction to a certain spread of situations. ${ }^{77}$ But Canguilhem's treatment of this habit as reflex is surely too rigid, and it ignores the dynamism of the general idea as it moves between generality and singularity: the geometrical idea is simply a particularly frozen version of the general idea in Bergson. ${ }^{78}$ In treating the general idea as deriving from a physiological habit, Canguilhem dramatically oversimplifies the relationship between memory, action, and image at work in this crucial chapter.

3. Finally, Canguilhem had suggested that Bergson moves from a "physiological" account of general ideas in Matter and Memory to one based in the things themselves in The Creative Mind. Bergson's ontology of images and his rejection of idealism and realism in the earlier work already gave us pause about the accuracy of this interpretation. For our present purposes, however, the fundamental error Canguilhem commits is to ignore the specificity of biological resemblance in this later work. The mistake is encapsulated in a line that Canguilhem attributes to Bergson, but that I have been unable to locate in the latter's corpus: "Life works as if it wanted to reproduce the identical."79 In Creative Evolution, to be sure, Bergson does 
discuss the relationship between the two types of order, vital-voluntary and geometrical-automatic. ${ }^{80}$ Bergson does seem inclined there to speak to treat the generality of genus and species as like the repetition of inorganic forms , an imitation of matter by living beings. ${ }^{81}$ Yet he immediately refers the reader back to Chapter I, where the apparent repetition of a structure across organisms is not necessarily that of a mold "imprinted" (empreinte) upon a matter, but can also be taken as a sign of similar responses to common problems. ${ }^{82}$ Hence, Bergson distinguishes répéter (to repeat) and répliquer (to reply, to replicate). ${ }^{83}$ Indeed, the aim of this earlier discussion in the book was to show the similarity of forms that exist across "diverging lines of evolution." This replicative rather than repetitive generality arises, as we saw in remark (1) from the commonality of certain tendencies across different evolutionary lines, a commonality that should be distinguished from repetition of a single species form. To simplify somewhat, whereas Canguilhem raises the question of generality at the level of the species, Bergson underlines transpecific commonalities and suprageneric tendencies.

What Bergson does say in The Creative Mind is that "life works as if it itself had general ideas," but since he distinguishes between general ideas based on resemblance and general ideas based on identity, we should not infer that life works as if according to identity. ${ }^{84}$ In short, the repetition that life "wants to reproduce" (to quote Canguilhem's misquotation) could be one of resemblance and not of identity. The point is urgent because Bergson does not define biological resemblance as a failed identity in this late work. Whereas geometric identity is reached through the measurability of spatialized parts, the reality of biological resemblance is attainable from "art" (as in the naturalist's sketches) and is of a different order. ${ }^{85}$ This art doubtless corresponds to the art whereby living nature produces vital forms through a natural and non-mathematical logos. In this sense, as we have already noted, Canguilhem is right to detect an Aristotelian heritage. ${ }^{86}$ Once more, however, nothing in Bergson's approach rules out a collaboration between mathematical and artistic approaches to the knowledge of life. It is this dynamic collaboration of intuition and intelligence that appears to be lost on Canguilhem. ${ }^{87}$

\section{III}

I would like to close with two brief remarks, for, despite my conviction that Canguilhem's criticisms of Bergson largely miss the mark, I also think there are two crucial points of profound contact with Bergson in Canguilhem's late thought.

1. I have already expressed my skepticism about the project of deriving the epistemic concept from the genetic code. Canguilhem's truly provocative insight is rather to have linked the distinctiveness and normativity of biological concepts to the normativité of living beings: their tendency to 
institute their own values, to live according to their own norms, gives a real "pretext" in the living being for the concepts that seek to comprehend life. ${ }^{88}$ In "Le problème de la normalité dans l'histoire de la pensée biologique," written in 1973, Canguilhem once more reflects on the specificity of the history of the biological sciences and on an overly discontinuist notion of this history. Whereas Dmitri Mendeleev hardly confirms the "intuitions" of Democritus, modern genetics does justify to a certain extent the "metaphors" of homeostasis and regulation of Claude Bernard through a "displacement" of these concepts' initial content and their reconfiguration as "indices of an objective originality." 89 The great value of this essay as a complement to "Le concept et la vie" is that it gives real examples of biological concepts and their peculiar nature, e.g., normality, homeostasis, and regulation. Much more clearly than in "Le concept et la vie," Canguilhem argues that biological knowledge is responsive to a kind of "given" in the thing to be known, "une donnée de la vie": not its genetic code per se, but rather the living being as "self-conservation through selfregulation."90 The concept is "in" life as a vital order based on the maintenance of "a system in unstable dynamic equilibrium, maintained in its ordered structure by a continual borrowing of energing at the expense of a milieu characterized by molecular disorder or by the frozen order of the crystal;" 91 this system is a "viable but fallible" form that is the historically contingent outcome of a process of evolution. ${ }^{92}$ Such an order is not an imitation of geometrical identity, but rather the expression of the normativity of living beings at every level. The order is something "instituted by life itself," as Jean Gayon puts, rightly seeing here a similarity between Canguilhem and Bergson. ${ }^{93}$

2. Both Bergson and Canguilhem agree that knowledge has a history that is not merely the sign of the weakness of the human mind. In his objection to Laplace, Bergson insists that time is not merely an illusion with which an omniscient god could dispense, and he must surely also mean the time of knowing. ${ }^{94}$ But just as the sense of life and the sense in life is founded, for Canguilhem, on the possibility of going astray - of errorknowledge in its historicity gets its normativity as the rectifying and overcoming of errors and obstacles. ${ }^{95}$ The primacy of error and errancy in Canguilhem's thought is perhaps what most radically distinguishes him from Bergson. ${ }^{96}$ Epistemically, it is the power of free judgment to affirm the false that affords the possibility of the imaginary, of the proliferation of images that allow scientific knowledge to reach beyond its present and anticipate its future. More work needs to be done on the possible connection between Canguilhem's theory of error and his theory of the imaginary. ${ }^{97}$ Indeed, many of Canguilhem's histories (of the reflex, of the cell) emphasize the productivity of images in the history of scientific thought. As for Bernard's metaphor of self-conservation, that we can now speak of it in less metaphorical terms (namely at the molecular level), does not mean that we 
have undergone a successful purging of our previous images, but only that they have been "displaced." 98

If Canguilhem seems to think that Bergson lacks a proper theory of the imaginary because of his refusal of negativity, his emphasis on the productive role of images is quite close to Bergson's own developed understanding of the relationship between intuition, image, and concept. Intuitions are incapable of being captured in words, and yet they pass over with a kind of necessity (as Bergson puts it in a 1936 letter to Floris Delattre) into images, which in turn enclose an ensemble of ideas, difficulties, and things unknown (les ignorances). ${ }^{99}$ The élan vital is just such an image:

[T] he image intervenes most often because it is indispensable, none of the other existing concepts being able to express the author's thought; the author is then obliged to present it suggestively [obligé de la suggérer]. This suggestion can only come about by way of an image, but an image that the philosopher has not chosen, one that as the sole means of communication and that imposes itself with an absolute necessity. To give just one example: when I relate the phenomena of life and of evolution to an "élan vital," it is in no way an ornament of style. It is even less meant to mask in images our ignorance of the deepest causes, as when the vitalist in general invokes a "vital principle." [...] The truth is that philosophy only offers philosophers two principles of explanation in this matter: mechanism and finalism. [...] Now [...] the place to be is somewhere in between these two concepts. How should we determine that place? I have to point to it, to indicate it [il faut bien que je l'indique $d u$ doigt] since no concept between mechanism and finality exists. The image of an élan is only this indication. ${ }^{100}$

Crucially, the indexical character of the image is not an injunction to halt one's thinking, but to create new concepts. It is hard not to be struck here by the fact that both Canguilhem and Bergson see a role in biological knowledge for the image; it is also hard not be struck by the non-arbitrary nature of the image, indeed by its necessity, by which Bergson must mean that its normativity for thought is quasi-apodictic.

Strikingly, a decade prior to "Le concept et la vie," Canguilhem had himself glimpsed this proximity between Bergson's thought on images and the Bachelardian approach to the history of the sciences that he was in the process of adopting. Bachelard's challenge to the Enlightenment conception of rationalism was to insist that a certain kind of error, the "epistemological obstacle," is actually a creative "force;"101 the progress of knowledge is not the systematic expulsion of images, but rather depends upon a boundlessness production of images. Canguilhem writes,

Just as materiality and the science of matter only retain, in Bergson's eyes, some positivity through their relation to the élan 
vital whose direction [sens] they invert, so too do the aggressive rationalization of the real and the violence of knowledge only seem to reside, according to $\mathrm{M}$. Bachelard, in the dialectical process of negation that inverts the direction of a sort of imaging élan [élan imageant]. ${ }^{102}$

Canguilhem reads the difficult question of the relationship between Bachelard's epistemological works and his studies of images as having ultimately ontological implications: a non-identitarian theory of Being as poiesis, much as Bergson's durée implies continuous creation and upsurge of novelty. ${ }^{103}$

Today, Canguilhem is often treated as a representative of French historical epistemology, and his final reckoning with Bergson in "Le concept et la vie" would seem to attest his move from a more speculative philosophy of life and interest in vitalism to a more sober concern for the history of the life sciences. In criticizing Canguilhem's interpretation of Bergson, my aim has not been to dismiss Canguilhem, but rather to retrieve those points that are most philosophically fertile in his thought and that rejoin the position that Bergson achieved: an ontological point of view from which he could think the openness and dynamism of order and intelligibility without succumbing to the traditional alternatives of idealism and realism. A renewed dialogue with Bergson's philosophy, "provided," as Canguilhem himself recognized, "that one read it without prejudice," would perhaps stimulate the current project to place his epistemology back into a larger set of philosophical concerns. ${ }^{104}$

1 Michel Foucault, "La vie: l'expérience et la science," in Dits et écrits, ed. Daniel Defert and Franc,ois Ewald, vol. 2 (Paris: Gallimard, 2001), 1583.

${ }^{2}$ Georges Canguilhem, “Mort de l'homme ou épuisement du cogito?," Critique, no. 242 (1967): 616; see more generally the attacks on Sartre in Georges Canguilhem, Vie et mort de Jean Cavaillès (Paris: Editions Allia, 2004); for the pre-history of Foucault's distinction, see Pierre CassouNoguès, "The Philosophy of the Concept," in Phenomenology: Responses and Developments, ed. Leonard Lawlor, vol. 4, 8 vols., The History of Continental Philosophy (Routledge, 2014), 217-34; a numbers of essays critical of this distinction are gathered in Pierre Cassou-Noguès and Pascale Gillot, eds., Le concept, le sujet et la science: Cavaillès, Canguilhem, Foucault, Problèmes et controverses (Paris: Vrin, 2009).

3 Jean Gayon, "Bergson's Spiritualist Metaphysics," in Continental Philosophy of Science, ed. Gary Gutting (Oxford: Blackwell, 2005), 43. Among other works by Deleuze, see notably Gilles Deleuze, Bergsonism, trans. Hugh Tomlinson and Barbara Habberjam (New York: Zone Books, 1988). 
${ }^{4}$ See Stefanos Geroulanos, "Beyond the Normal and the Pathological: Recent Literature on Georges Canguilhem," Gesnerus 66.2 (2009): 288-306. Geroulanos also notes the dearth of scholarly attention to Canguilhem's relationship to Bergson (304-5).

${ }^{5}$ Dominique Lecourt, Marxism and Epistemology: Bachelard, Canguilhem and Foucault, trans. Ben Brewster (London: NLB, 1975). (Published in French as Dominique Lecourt, Pour une critique de l'épistémologie : Bachelard, Canguilhem, Foucault, Théorie (Paris: Maspero, 1972).). Lecourt wrote his master's thesis on Bachelard under Canguilhem and then added several additional essays to produce this volume. This way of reading Canguilhem as part of triad including Bachelard and Foucault can also be seen in Gary Gutting, Michel Foucault's Archaeology of Scientific Reason (New York: Cambridge University Press, 1989); Jean-François Braunstein, "Bachelard, Canguilhem, Foucault: Le 'style français' en épistémologie," in Les philosophes et la science, ed. Pierre Wagner and Jean-François Braunstein, 408 (Paris: Gallimard, 2002), 92063.

${ }^{6}$ Since 2011, two massive volumes of Canguilhem's complete works have been published: Georges Canguilhem, CEuvres complètes: Écrits philosophiques et politiques: 1926 - 1939, ed. JeanFrançois Braunstein and Jacques Bouveresse, vol. I (Paris: Vrin, 2011); Georges Canguilhem, CEuvres complètes: Résistance, philosophie biologique et histoire des sciences: (940 - 1965, ed. Camille Limoges, Jacques Bouveresse, and Jean-François Braunstein, vol. 4 (Paris: Vrin, 2015). For the need to revise the "historical epistemology" reading of Canguilhem, see Camille Limoges, "Introduction: Philosophie Biologique, Histoire Des Sciences et Interventions Philosophiques: Georges Canguilhem, 1940-1965," in CEuvres Complètes, by Georges Canguilhem, vol. IV (Paris: Vrin, 2015), 29, 38.

7 This relationship has not been deeply explored. For an important exception, see Guillaume Le Blanc, Canguilhem et la vie humaine (Paris: PUF, 2010), 335-349. I am more skeptical than Le Blanc of the accuracy of Canguilhem's reading of Bergson.

8 Translation modified. "[L]a philosophie est une réflexion pour qui toute matière étrangère est bonne, et nous dirions volontiers pour qui toute bonne matière doit être étrangère" Georges Canguilhem, Le normal et le pathologique (Paris: PUF, 1966), 7; Georges Canguilhem, The Normal and the Pathological, trans. Carolyn R. Fawcett, 5th printing (New York: Zone Books, 2007), 33. For the importance of this passage in Canguilhem's thought, see Luca Paltrinieri, $L^{\prime}$ expérience du concept: Michel Foucault entre épistémologie et histoire (Paris: Publications de la Sorbonne, 2012), 26.

9 Georges Canguilhem, La connaissance de la vie, 2nd ed., Bibliothèque des textes philosophiques (Paris: Vrin, 2015), 47. (According to the pagination of the 1965 edition, printed in the margin of subsequent editions.)

${ }^{10}$ Georges Canguilhem, "Le concept et la vie," in Études d'histoire et de philosophie des sciences, 7th ed. (Paris: Vrin, 2002), 335-64. A partial translation can be found in Georges Canguilhem, $A$ Vital Rationalist: Selected Writings from Georges Canguilhem, ed. Francois Delaporte (New York: Zone Books, 1994), 303-319 but it does not contain many of the passages I will examine in this paper. All translations provided in this text are my own.

${ }^{11}$ As a young man, Canguilhem was hostile to Bergson (Georges Canguilhem, "Review of Georges Politzer, La fin d'une parade philosophique : le bergsonisme. 20 April 1929," in CEuvres complètes: Écrits philosophiques et politiques: 1926 - 1939, by Georges Canguilhem, ed. JeanFrançois Braunstein and Jacques Bouveresse, vol. I, CEuvres complètes (Paris: Librairie Philosophique Vrin, 2011), 221-28.) For Canguilhem's changing attitude toward Bergson, see Jean-François Braunstein, "A la découverte d'un 'Canguilhem perdu,"” in CEuvres complètes: 
Écrits philosophiques et politiques: 1926 - 1939, by Georges Canguilhem, ed. Jean-François Braunstein and Jacques Bouveresse, vol. I, CEuvres complètes (Paris: Librairie Philosophique Vrin, 2011), 135-137. After 1966, he had almost nothing to say about Bergson, apart from a brief mention in an encyclopedia article. In an interview just before his death, he referred to "Le concept et la vie" as his final word on Bergson: Francois Bing and Jean-François Braunstein, "Entretien avec Georges Canguilhem, réalisé le 21 juin 1995," in Actualités Georges Canguilhem: Le Normal et le pathologique (Paris: Synthélabo, 1998), 129.

${ }^{12}$ Canguilhem, "Le concept et la vie," 337-339.

${ }^{13}$ Ibid., 362.

${ }^{14}$ Ibid., 364.

15 Ibid., 335.

${ }^{16}$ For this formulation see Pierre Macherey, De Canguilhem à Foucault: la force des normes (Paris: Fabrique, 2009), 100.

${ }_{17}$ Canguilhem, "Le concept et la vie," 335.

18 Ibid., 336.

19 lbid., 337.

20 Ibid.

${ }^{21}$ Henri Bergson, L'évolution créatrice, ed. Frédéric Worms, 12. éd, Quadrige (Paris: PUF, 2013); Henri Bergson, Creative Evolution (Westport, Conn: Greenwood Pr, 1975).

${ }^{22}$ Canguilhem, "Le concept et la vie," 338-9.

${ }^{23}$ For a discussion of the debate around the success or failure of Bergson's overcoming of Platonism, see Leonard Lawlor, The Challenge of Bergsonism: Phenomenology, Ontology, Ethics (London: Continuum, 2003), 28ff.

${ }^{24}$ Canguilhem, "Le concept et la vie," 354, 362.

${ }^{25}$ We should not forget that Bergsonism was a general cultural phenomenon in the early twentieth century. "Bergsonisme" as the name of this phenomenon (and often as a derogatory label for what was seen as a fad) entered into wide circulation in 1912 and is to be found in the title of Georges Politzer's scathing attack in 1929. See Giuseppe Bianco, Après Bergson: portrait de groupe avec philosophe (Paris: PUF, 2015), 11.

${ }^{26}$ For an earlier and somewhat different approach the the relationship between knowledge and life, see Canguilhem, La connaissance de la vie, 11-13 and passim.

${ }^{27}$ Henri Bergson, Matière et mémoire: essai sur la relation du corps à l'esprit, ed. Frédéric Worms and Camille Riquier (Paris: Presses universitaires de France, 2012), 172. Henri Bergson, Matter and Memory (New York: Zone books, 1988).

${ }^{28}$ Canguilhem, “Le concept et la vie," 348-354.

29 Henri Bergson, La pensée et le mouvant: essais et conférences, 17. éd. "Quadrige," Quadrige Grands textes (Paris: Presses Univ. de France, 2013); Henri Bergson, The Creative Mind: An Introduction to Metaphysics, trans. Mabelle L Andison (Mineola, NY: Dover Publications, 2007). 
${ }^{30}$ Bergson, L'évolution créatrice, 361; Bergson, Creative Evolution, 362; cited in Canguilhem, "Le concept et la vie," 348.

${ }^{31}$ Canguilhem, "Le concept et la vie," 348.

32 See Bergson, L'évolution créatrice, 103; Bergson, Creative Evolution, 104; see Bergson, La pensée et le mouvant, 31.

${ }^{33}$ Bergson, Matière et mémoire, 169-178; Bergson, Matter and Memory, 156-163.

${ }^{34}$ Bergson, Matière et mémoire, 173; Bergson, Matter and Memory, 158-9; cited in Canguilhem, "Le concept et la vie," 349.

35 Translation modified (the English renders ressemblance as "similarity" Bergson, Matière et mémoire, 175; Bergson, Matter and Memory, 160.

${ }^{36}$ Canguilhem, "Le concept et la vie," 349.

37 Ibid., 348.

${ }^{38}$ Bergson, La pensée et le mouvant, 55; Canguilhem, “Le concept et la vie," 351.

39 Bergson, La pensée et le mouvant, 57-58; Bergson, The Creative Mind, 63-64; partially quoted in Canguilhem, "Le concept et la vie," 350.

${ }^{40}$ Bergson, La pensée et le mouvant, 60; Bergson, The Creative Mind, 66.

${ }^{41}$ Bergson, La pensée et le mouvant, 58.

${ }^{42}$ Canguilhem, "Le concept et la vie," 352.

43 "L'élan est fini et il a été donné une fois pour toutes" (Bergson, L'évolution créatrice, 254). Jankélévitch and this passage are cited in Canguilhem, "Le concept et la vie," 353. I have been unable to locate the precise passage in question in Jankélévitch, but he does discuss the relationship between life and matter at Vladimir Jankélévitch, Henri Bergson, ed. Alexandre Lefebvre, trans. Nils F Schott (Durham: Duke University Press, 2015), 137-150.

44 Bergson, L'évolution créatrice, 99. Canguilhem does nod to Bergson's attempt to reconcile monism and dualism, but sees the project as vague and ambiguous (Canguilhem, "Le concept et la vie," 354). He appears to think that Bergson ultimately fails to conceive of matter as anything other than negativity with respect to spirit or life.

45 "Le maintien actif d'une forme, et d'une forme spécifique" (Canguilhem, "Le concept et la vie," 354). Indeed, Canguilhem was to repeat this same criticism several years after his supposed last word on Bergson. Georges Canguilhem, "Vie," Encylopaedia Universalis (Paris: Encyclopaedia Universalis, 1974), 768.

${ }^{46}$ Canguilhem, "Le concept et la vie," 364.

47 Ibid., 362. In the New Reflections appended to the 1966 edition of The Normal and the Pathological, Canguilhem goes so far as to say, "Heredity is the modern name of substance" (Canguilhem, Le normal et le pathologique, 211).

${ }^{48}$ Michel Morange, "Georges Canguilhem et la biologie du XXe siècle," Revue d'histoire des sciences 53, no. 1 (2000): 90 . Morange also criticizes Canguilhem for thinking that progress in biology is simply progressive mathematization, a position that Canguilhem himself had once rejected. "La biologie n'est toujours pas la mise en forme mathématique" (88). 
${ }^{49}$ Canguilhem, "Le concept et la vie," 364.

${ }^{50}$ See also Canguilhem, Le normal et le pathologique, 209.

${ }^{51}$ Canguilhem, “Le concept et la vie," 364.

${ }^{52}$ Bergson, L'évolution créatrice, ix; Bergson, Creative Evolution, xiii.

${ }^{53}$ Bergson, L'évolution créatrice, 190-191; Bergson, Creative Evolution, 189-190.

${ }^{54}$ Bergson, L'évolution créatrice, 99; Bergson, Creative Evolution, 98.

${ }^{55}$ Bergson, L'évolution créatrice, 136-7; Bergson, Creative Evolution, 135-6.

${ }^{56}$ Bergson, L'évolution créatrice, 119; Bergson, Creative Evolution, 118.

${ }^{57}$ Bergson, L'évolution créatrice, 144; Bergson, Creative Evolution, 143.

${ }^{58}$ Bergson, L'évolution créatrice, 207ff; Bergson, Creative Evolution, $205 \mathrm{ff}$.

${ }^{59}$ Bergson, Matière et mémoire, i; Bergson, Matter and Memory, 9.

${ }^{60}$ Bergson, Matière et mémoire, iii-iv; Bergson, Matter and Memory, 11.

${ }^{61}$ For the history of the word "epistemology" in English and its difference from the French usage, see Braunstein, "Bachelard, Canguilhem, Foucault: Le 'style français' en épistémologie," 930931.

${ }^{62}$ Bergson, Matière et mémoire, xi-xii; Bergson, Matter and Memory, 15-16.

${ }^{63}$ See Bergson, La pensée et le mouvant, 68, 108.

${ }^{64}$ Ibid., 69n.

${ }^{65}$ On life as resolution of problems, see Bergson, L'évolution créatrice, 59, 71, 78, 144.

66 Ibid., 156-158.

67 Ibid., 166.

${ }^{68}$ For a summary of some of these traditional misreadings of intuition, see Pete A. Y. Gunter, "Bergson's Philosophical Method and Its Applications to the Sciences," The Southern Journal of Philosophy 16.3 (Fall 1978): 168ff.

${ }^{69}$ Bergson, La pensée et le mouvant, 10.

70 Bergson, L'évolution créatrice, 4, 7.

71 Ibid., 361; Bergson, Creative Evolution, 362; cited in Canguilhem, “Le concept et la vie," 348.

${ }^{72}$ Bergson, L'évolution créatrice, 19-20.

${ }^{73}$ Ibid., 259; Bergson, Creative Evolution, 258. Translation heavily modified. Mitchell distorts this relationship between the virtual (which he translates as "potential") and the actual in a number of ways. He transforms the exteriorization of the virtual multiplicity from a real operation into merely a matter of "regard," and he does not preserve Bergson's verb tenses. Moreover, by rendering "ce que la vie porte en elle" as "life's own inclination," he misses what is crucial: life is already, virtually differentiated. Finally, I have replaced Mitchell's "contact with matter is what determines this dissociation" to decides (décide de cette dissociation) because matter is merely decisive (in the etymological sense) in this process, not determinative. 
${ }^{74}$ Bergson, La pensée et le mouvant, 19; Bergson, The Creative Mind, 27.

75 Pete A. Y. Gunter, "Bergson's Creation of the Possible," SubStance 36.3 (January 1, 2007): 39, doi:10.1353/sub.2007.0043.

76 For Bergson's lengthy symmetrical critique of mechanistic and finalistic (or teleological) explanations of transformism, see in particular Bergson, L'évolution créatrice, 39-98.

77 Bergson, Matière et mémoire, 172-176; Bergson, Matter and Memory, 157-161.

78 On the "dynamism" of the general idea, see Lawlor, The Challenge of Bergsonism, 50, 52. See also Bergson, Matière et mémoire, 176; Bergson, Matter and Memory, 161.

79 "La vie travaille comme si elle voulait reproduire l'identique" (Canguilhem, "Le concept et la vie," 352). Canguilhem is presumably still discussing The Creative Mind here, but he is perhaps citing from memory. No page number is given in the text.

${ }^{80}$ Bergson, L'évolution créatrice, 224-232; Bergson, Creative Evolution, 223-231.

${ }^{81}$ Bergson, L'évolution créatrice, 231-2; Bergson, Creative Evolution, 230-231.

82 See Bergson, L'évolution créatrice, 58, 71.

${ }^{83}$ Ibid., 58.

${ }^{84}$ Bergson, La pensée et le mouvant, 58; Bergson, The Creative Mind, 64.

${ }^{85}$ Bergson, La pensée et le mouvant, 60; Bergson, The Creative Mind, 66; Bergson, L'évolution créatrice, 224; Bergson, Creative Evolution, 223.

${ }^{86}$ There is a larger background disagreement here on the relationship between art and technique. For Canguilhem's criticisms of Bergson, which prefigure much of what he will have to say about negativity and error later, see Georges Canguilhem, "Réflexions sur la création artistique selon Alain," Revue de Métaphysique et de Morale 57.2 (1952): 185-6.

${ }^{87}$ For a recent appreciation of this collaborative role of intuition, see Gayon, "Bergson's Spiritualist Metaphysics." A classical treatment can be found in Léon Husson, L'intellectualisme de Bergson: Genèse et développement de la notion bergsonienne de l'intuition (Paris: PUF, 1947).

${ }^{88}$ For Canguilhem's definition of normativité as the capacity of the organism to institute new norms for itself, see Canguilhem, Le normal et le pathologique, 77. On the unity of Canguilhem's medical thought of norms and his epistemological history of biology, see Guillaume Le Blanc, Canguilhem et les normes (Paris: Presses universitaires de France, 2007).

${ }^{89}$ Georges Canguilhem, "Le problème de la normalité dans l'histoire de la pensée biologique," in Idéologie et rationalité dans l'histoire des sciences de la vie, 2nd ed. (Paris: Vrin, 1981), 138.

90 Ibid., 124.

91 Ibid., 134.

92 Ibid., 138.

${ }_{93}$ Gayon, "Bergson's Spiritualist Metaphysics," 57.

${ }^{94}$ Bergson, L'évolution créatrice, 38.

${ }^{95}$ Georges Canguilhem, “Objectivité et Historicité,” Raison Présente 8 (1968): 39. 
96 Canguilhem, "Réflexions sur la création artistique selon Alain," 185. For the genesis of Canguilhem's properly philosophical concern with error, see Samuel Talcott, "Georges Canguilhem and the Philosophical Problem of Error,” Dialogue 52.4 (December 2013): 649-72.

97 See also Georges Canguilhem, “De la science et de la contre-science," in Hommages à Jean Hyppolite (Paris: PUF, 1971), 175.

${ }^{88}$ Canguilhem, “Le problème de la normalité dans l’histoire de la pensée biologique,” 138.

99 Bergson italicizes "les ignorances" in the letter: Henri Bergson and Floris Delattre, "Samuel Butler et le bergsonisme. Avec deux lettres inédites d'Henri Bergson,” Revue anglo-américaine, June 1936, 399. He is referring to his discussion of the élan vital in his final original book Henri Bergson, Les deux sources de la morale et de la religion, ed. Frédéric Keck and Ghislain Waterlot (Paris: PUF, 2013), 115-120. The relevant passage in the letter to Delattre is reprinted in Henri Bergson, Mélanges, ed. André Robinet (Paris: PUF, 1972), 1526-7.

100 My translation. Bergson and Delattre, "Samuel Butler et le bergsonisme. Avec deux lettres inédites d'Henri Bergson," 399. On the relationship between intuition, image, and concept, see also Bergson, La pensée et le mouvant, 45, 171-186.

101 Georges Canguilhem, "Sur une épistémologie concordataire," in Hommage à Gaston Bachelard: Etudes de philosophie et d'histoire des science (Paris: PUF, 1957), 10.

102 lbid., 9.

103 Ibid., 12.

104 Georges Canguilhem, “Note sur la situation faite en France à la philosophie biologique," Revue de métaphysique et de morale 52 (1947): 332. 